\title{
Analiza stanu nasiennictwa wybranych gatunków traw i bobowatych drobnonasiennych w Polsce na tle rynku europejskiego
}

\author{
Analysis of the seed production status of selected species of grasses and legumes \\ in Poland on the background of the European market
}

\section{Piotr Goliński $\bowtie$, Barbara Golińska}

Katedra Łąkarstwa i Krajobrazu Przyrodniczego, Uniwersytet Przyrodniczy w Poznaniu, Dojazd 11, 60-632 Poznań,

$\triangle$ e-mail: pgolinsk@up.poznan.pl

\begin{abstract}
Wykorzystujac dane ESCAA z lat 2004-2019 przeprowadzono analizę stanu nasiennictwa wybranych gatunków traw i bobowatych drobnonasiennych w Polsce w aspekcie powierzchni upraw nasiennych oraz poziomu ich plonowania na tle rynku europejskiego. Szczególną uwagę w analizie zwrócono na gatunki dominujące w areale reprodukcyjnym odmian tych grup roślin w Polsce oraz w Europie, a więc Lolium perenne L., Lolium multiflorum Lam., Festuca rubra L. oraz Trifolium pratense L. Stwierdzono, że z upływem lat znaczenie polskiego rynku nasiennego traw w Europie rośnie. W 2019 roku udział naszego kraju w areale zakwalifikowanych plantacji nasiennych traw w Europie wyniósł 12\%. W latach 2016-2019 udział ten zwiększył się o 56\% i był obok Danii (60\%) jednym z największych na kontynencie europejskim. Obecnie Polska zajmuje drugie miejsce w uprawie Lolium multiflorum i Festuca rubra, a w przypadku Lolium perenne jest jednym $\mathrm{z}$ trzech najważniejszych krajów rynku europejskiego. W uprawie na nasiona roślin bobowatych drobnonasiennych Polska ma mniejsze znaczenie w Europie, jednak w przypadku Trifolium pratense posiada znaczący udział w rynku nasiennym z wyraźnym trendem wzrostu powierzchni plantacji tego gatunku w ostatnich latach. Plony nasion z plantacji nasiennych traw i bobowatych drobnonasiennych w Polsce są mniejsze w porównaniu do wielu krajów europejskich, toteż zwiększenie wydajności upraw nasiennych jest warunkiem dalszej ekspansji naszego kraju w tym segmencie rynku nasiennego w Europie.
\end{abstract}

Słowa kluczowe: nasiennictwo, trawy, koniczyna łąkowa, plon nasion

Using the ESCAA data from 2004-2019, an analysis was carried out on the status of seed production of selected species of grasses and legumes in Poland in terms of the area of seed crops and their seed yield on the background of the European market. Particular attention in the analysis was paid to the dominant species in the reproductive area of varieties of this group of plants in Poland and in Europe, i.e. Lolium perenne L., Lolium multiflorum Lam., Festuca rubra L. and Trifolium pratense L. It was found that over the years, the importance of the Polish grass seed market in Europe is growing. In 2019, our country's share in the area of certified grass seed plantations in Europe was $12 \%$. In the years 2016-2019, this share has increased by 56\% and was next to Denmark $(60 \%)$ one of the largest on the European continent. Currently, Poland ranks second in the area of seed crops of Lolium multiflorum and Festuca rubra, and in the case of Lolium perenne is one of the three leading European market countries. In legumes grown for seeds, Poland is less important in Europe, however, in the case of Trifolium pratense, it is in recent years a significant player on the seed market with a clear trend of increasing the plantations area of this species. Harvested seed yields from grasses and legumes grown for seeds in Poland are lower compared to many European countries, so increasing seed yield is a prerequisite for our country's further expansion in this segment of the seed market in Europe.

Key words: seed production, grasses, red clover, seed yield

\section{Wstęp}

Nasiennictwo traw i bobowatych drobnonasiennych pozostaje ważną częścią rynku nasiennego roślin rolniczych w Polsce i w Europie. Specyfika tej grupy roślin uprawnych, określanych popularnie łąkowymi, wynika $\mathrm{z}$ różnorodnych właściwości użytkowych oraz wymagań siedliskowych poszczególnych taksonów, a także $\mathrm{z}$ dużej liczby gatunków uwzględnionych w regulacjach prawnych dotyczących rejestracji ich odmian hodowlanych oraz wytwarzania, oceny i kontroli materiału siewnego. Zapotrzebowanie na nasiona poszczególnych gatunków traw i bobowatych drobnonasiennych wyznacza nie tylko rolnictwo, ale również inne sektory gospodarki (Goliński i in., 2005; Kozłowski i Goliński, 2000). Podstawowym celem reprodukcji odmian tej grupy roślin jest wytwarzanie materiału siewnego do zakładania i renowacji użytków zielonych $\mathrm{w}$ celu produkcji wartościowej paszy dla zwierząt trawożernych (Martyniak, 2009). Największe potrzeby doskonalenia bazy paszowej 
występują w chowie krów mlecznych (Bailey i in., 2016; Goliński i in., 2014; Huyghe i in., 2014; Van den Pol-van Dasselaar i in., 2014; Wachendorf i Goliński, 2006). W przypadku traw na stan nasiennictwa wpływa $\mathrm{w}$ dużym stopniu wykorzystanie nasion do celów pozapaszowych, w tym darniowych i trawnikowych (Goliński i in., 2005). Warto nadmienić, że po wstąpieniu naszego kraju do Unii Europejskiej wzajemne powiązania i oddziaływania rynkowe w nasiennictwie traw i bobowatych drobnonasiennych są coraz większe, zwłaszcza w odniesieniu do poziomu produkcji, kształtowania się cen oraz opłacalności (Goliński i Golińska, 2016).

Obecnie w naszym kraju produkcja nasienna traw koncentruje się na następujących gatunkach: Lolium perenne L., Lolium multiflorum Lam., Lolium westerwoldicum R.Br., Lolium $x$ hybridum Hausskn., Festuca rubra L., Festuca pratensis Huds., Festuca arundinacea Schreber, Dactylis glomerata L. i Phleum pratense L. Świadczy o tym ich udział $\mathrm{w}$ areale zakwalifikowanych plantacji nasiennych w ostatnich latach. W przypadku bobowatych drobnonasiennych największe znaczenie na rynku nasiennym mają koniczyny i lucerny. Wiodącą rolę w naszym kraju odgrywa Trifolium pratense $\mathrm{L}$.

O opłacalności upraw nasiennych traw i bobowatych drobnonasiennych decyduje cena nasion oraz koszty produkcji. Największe znaczenie w opłacalności produkcji nasion tej grupy roślin ma jednak wielkość zbieranego plonu (Goliński, 1996). Plon nasion traw i bobowatych drobnonasiennych zależy od wielu czynników, stymulujących biologiczny potencjał plonowania oraz ograniczających straty (Boelt i Studer, 2010; Goliński i in., 2005; Goliński, 2012).

Celem pracy jest analiza stanu nasiennictwa wybranych gatunków traw i bobowatych drobnonasiennych w Polsce w aspekcie powierzchni upraw nasiennych oraz poziomu ich plonowania na tle rynku europejskiego.

\section{Material i Metody}

W pracy wykorzystano dane European Seed Certification Agencies Association (ESCAA) z lat 2004-2019 dotyczące areału zakwalifikowanych upraw nasiennych traw i bobowatych (motylkowatych) drobnonasiennych oraz wielkości produkcji kwalifikowanych nasion gatunków objętych ewidencją tego stowarzyszenia. W odniesieniu do Polski dane te uzupełniano wynikami oceny polowej i laboratoryjnej podawanymi przez Państwową Inspekcję Ochrony Roślin i Nasiennictwa (PIORIN). Na podstawie danych źródłowych obliczono średni dla okresu 16 lat plon nasion z hektara wybranych gatunków traw i bobowatych drobnonasiennych (dzieląc całkowitą produkcję kwalifikowanych nasion przez areał zakwalifikowanych plantacji danego gatunku) oraz kierunki zmian w powierzchni upraw nasiennych tych grup roślin uprawnych w ostatnich czterech latach. Szczególną uwagę w analizie zwrócono na gatunki dominujące $\mathrm{w}$ areale reprodukcyjnym odmian traw i bobowatych drobnonasiennych w Polsce oraz w Europie, a więc życicę trwałą (L. perenne), życicę wielokwiatową (L. multiflorum), kostrzewę czerwoną (F. rubra) oraz koniczynę łąkową (T. pratense). $\mathrm{W}$ analizie uwzględniono kraje o największym areale reprodukcji odmian tych grup roślin na rynku europejskim.

\section{Wyniki i Dyskusja}

Najważniejszym gatunkiem spośród traw pastewnych i gazonowych na rynku nasiennym w Polsce, jak i w Europie, jest życica trwała. Jest to efektem szerokiego wykorzystania odmian hodowlanych tego gatunku, zarówno do celów paszowych, jak i pozapaszowych (Humphreys i in., 2010). Udział życicy trwałej w ogólnej powierzchni zakwalifikowanych plantacji nasiennych traw w naszym kraju wynosi w ostatnich latach około $40 \%$. Czynnikiem wyróżniającym życicę trwałą na rynku nasiennym traw w Polsce jest duży i stały, choć zróżnicowany w stosunku do poszczególnych odmian hodowlanych, popyt na nasiona. W efekcie powierzchnia plantacji nasiennych tego gatunku na przestrzeni ostatnich 16 lat systematycznie zwiększa się (rys. 1). Niekwestionowanym liderem w reprodukcji odmian życicy trwałej w Europie jest Dania, której areał zakwalifikowanych upraw nasiennych $\mathrm{w}$ ostatnich czterech latach szybko wzrastał, osiągając w 2019 roku rekordowy poziom 43861 ha. Polska z areałem oscylującym w ostatnich latach wokół 10000 ha należy do czołówki krajów uprawiających życicę trwałą na nasiona.

Ważną rolę w nasiennictwie traw pastewnych odgrywają życice krótkotrwałe, których odmiany są wykorzystywane do produkcji doskonałej jakości paszy, głównie z użytków przemiennych. Spośród kilku gatunków tej grupy życic najważniejszym jest L. multiflorum (Humphreys i in., 2010). Na rynku europejskim liderem w reprodukcji zróżnicowanych pod względem ploidalności odmian hodowlanych tego gatunku są Niemcy. W okresie 2004-2019 areał upraw nasiennych tej trawy u naszych zachodnich sąsiadów zmieniał się, jednak w ostatnich dwóch latach uwidocznił się wyraźny trend wzrostowy, przekraczając w ubiegłym roku 15000 ha (rys. 2). 


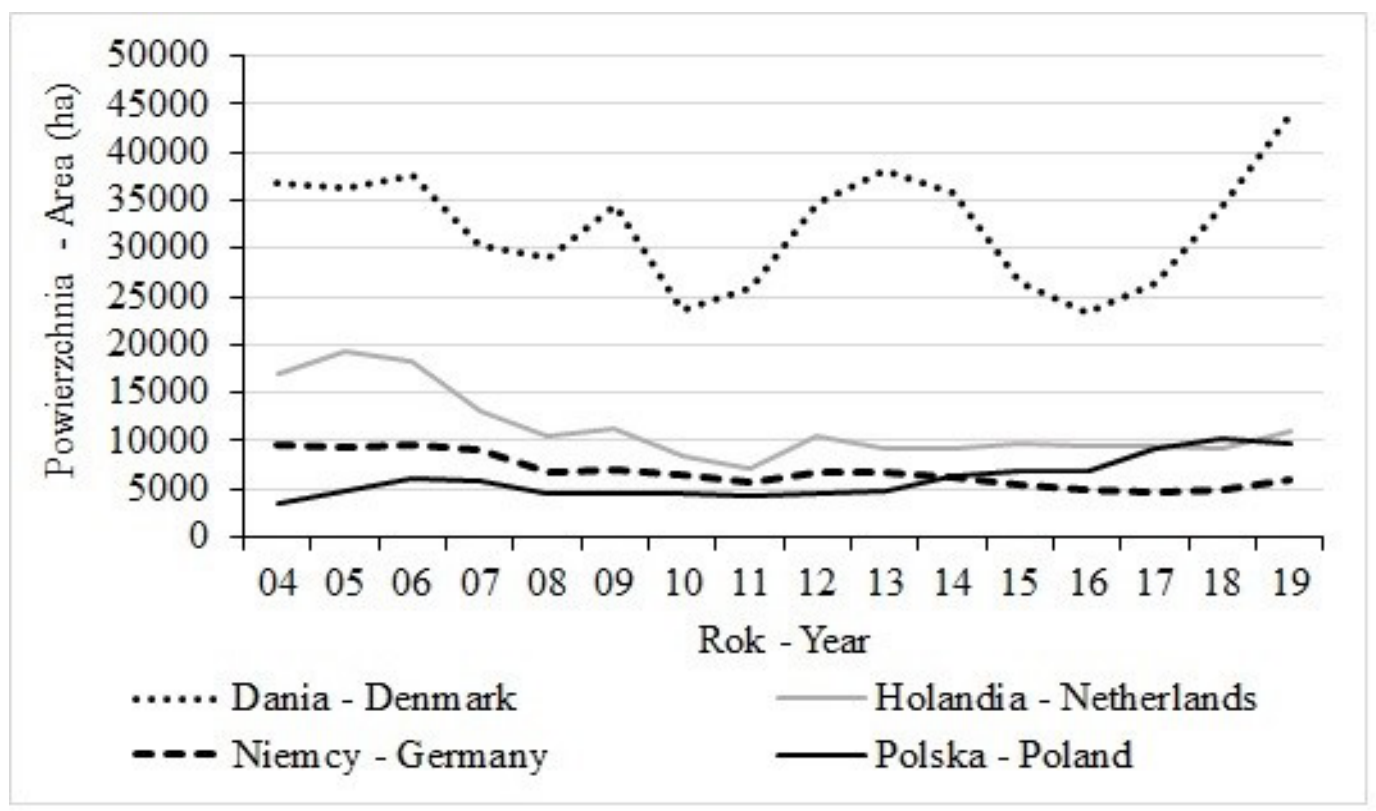

Rys. 1. Powierzchnia zakwalifikowanych upraw nasiennych życicy trwałej w wybranych krajach Europy w latach 2004-2019 (ha)

Fig. 1. Certified area of perennial ryegrass grown for seed in selected European countries in 2004-2019 (ha)

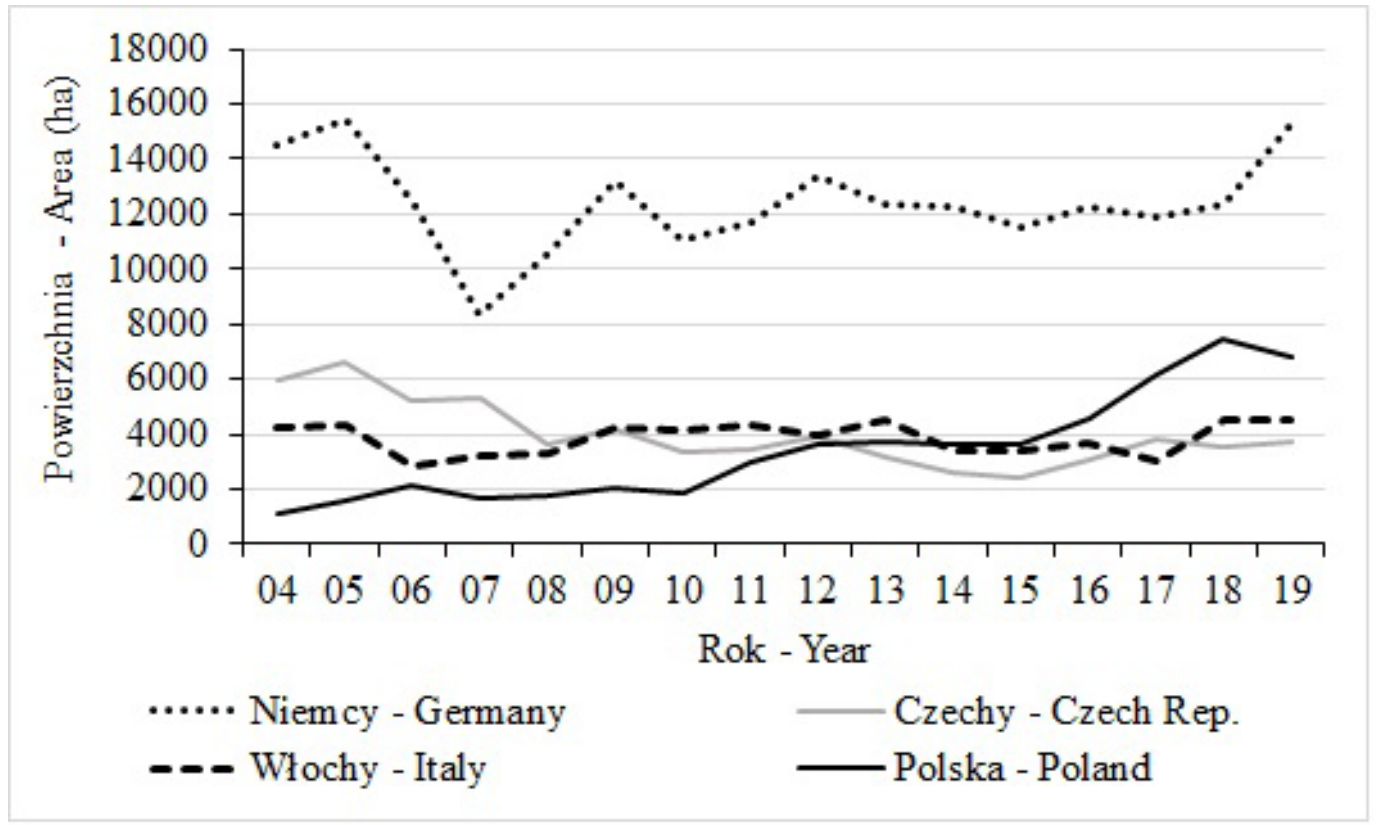

Rys. 2. Powierzchnia zakwalifikowanych upraw nasiennych życicy wielokwiatowej w wybranych krajach Europy w latach 2004-2019 (ha)

Fig. 2. Certified area of Italian ryegrass grown for seed in selected European countries in 2004-2019 (ha) 
W analizowanym okresie powierzchnia upraw nasiennych życicy wielokwiatowej w naszym kraju zwiększała się dynamicznie, dzięki czemu Polska w ostatnich pięciu latach zajmowała drugie miejsce w Europie.

Znaczący udział kostrzewy czerwonej w europejskim rynku nasiennym traw wynika z reprodukcji licznych odmian hodowlanych, wykorzystywanych głównie do celów darniotwórczych (Rognli i in., 2010). Materiał siewny zróżnicowanych pod względem właściwości biologicznych odmian, należących do kilku niższych od gatunku jednostek taksonomicznych, jest wykorzystywany do zakładania trawników, zadarniania skarp, poboczy dróg, terenów zlokalizowanych $\mathrm{w}$ trudnych warunkach siedliskowych, a także jako komponent do mieszanek na trwałe użytki zielone, zwłaszcza pastwiska, co generuje duże zapotrzebowanie na nasiona. Liderem w nasiennictwie kostrzewy czerwonej w Europie jest Dania. W analizowanym okresie areał upraw nasiennych odmian tej trawy był 4-5 krotnie większy niż w innych krajach europejskich (rys. 3). Znaczącą rolę w nasiennictwie kostrzewy czerwonej odgrywa Polska, zajmując w ostatnich latach drugą pozycję w Europie z areałem zakwalifikowanych plantacji na poziomie ponad 4000 ha.

Rosnące znaczenie roślin bobowatych drobnonasiennych na rynku nasiennym w Europie jest skutkiem promocji stosowania rodzimego białka w paszy podstawowej w żywieniu przeżuwaczy. Wiodącą rolę odgrywa reprodukcja odmian Medicago sativa L., głównie we Włoszech, Francji i Hiszpanii. W 2018 roku odmiany lucerny siewnej były namnażane na areale 115320 ha. Spośród koniczyn najważniejsza jest koniczyna łąkowa (Boller i in., 2010), reprodukowana w Europie na powierzchni około 37500 ha. Liderami w nasiennictwie tego gatunku są Francja i Czechy. W uprawie na nasiona roślin bobowatych drobnonasiennych Polska ma mniejsze znaczenie na rynku europejskim, jednak w przypadku $T$. pratense jest znaczącym producentem, zwiększając w ostatnich latach areał uprawy do poziomu około 5000 ha (rys. 4).

$\mathrm{W}$ analizie produkcji materiału siewnego traw i bobowatych drobnonasiennych $\mathrm{w}$ danym kraju istotna jest nie tylko powierzchnia reprodukcyjna poszczególnych odmian i taksonów, lecz także uzyskiwany plon nasion z jednostki powierzchni, który jest efektem potencjału nasiennego odmian hodowlanych (Boelt i Studer, 2010; Goliński i in., 2005) oraz prawidłowej agrotechniki stosowanej na plantacji (Rolston i in., 2007). Oceniając plon nasion najważniejszych roślin łąkowych w latach 2004-2019 w Europie (rys. 5), nasuwa się stwierdzenie, że liderzy na rynku nasiennym tej grupy roślin pod względem areału uprawy legitymują się także wysoką wydajnością plantacji nasiennych. Dotyczy to w odniesieniu do traw - Danii oraz Holandii, a w przypadku bobowatych - Francji i Włoch. Ciągłe doskonalenie technologii uprawy na nasiona życicy trwałej w Danii sprawia, że średni plon nasion odmian tego gatunku w badanym okresie osiągnął poziom $1747 \mathrm{~kg} \cdot \mathrm{ha}^{-1}$, dorównując w niektórych latach wydajności plantacji w Nowej Zelandii (Rolston i in., 2007). Zdecydowanie mniejsze plony z hektara uzyskiwano w Holandii oraz w Niemczech. Na tym tle średnia wydajność plantacji nasiennych życicy trwałej w Polsce, dla 16-letniego okresu analizy, kształtuje się na niskim poziomie $\left(846 \mathrm{~kg} \cdot \mathrm{ha}^{-1}\right)$. Mimo, iż w ostatnich latach obserwuje się wzrost plonu nasion tego gatunku w naszym kraju należy systematycznie dążyć do doskonalenia technologii produkcji nasion życicy trwałej z wykorzystaniem innowacji stymulujących potencjał biologiczny odmian pastewnych i trawnikowych np. otoczkowanie nasion (Qiu i in., 2020), regulatory wzrostu zapobiegające wyleganiu roślin (Goliński i in., 2008; Chastain i in. 2014), nawożenie dolistne mikroelementami (Hart i in., 2013), jak i ograniczających straty już wytworzonego plonu np. preparaty zapobiegające osypywaniu ziarniaków (Goliński i Golińska, 2015).

Zdecydowanie lepiej kształtuje się w Polsce plonowanie życicy wielokwiatowej (rys. 5). W badanym okresie wydajność plantacji nasiennych tego gatunku dorównuje plantacjom w Niemczech oraz jest o 13\% większa niż w Czechach. Dużym plonowaniem upraw nasiennych życicy wielokwiatowej wyróżniają się Włochy. W przypadku kostrzewy czerwonej, Dania jest nie tylko liderem w areale reprodukcyjnym odmian, lecz także zajmuje pierwsze miejsce pod względem wydajności plantacji $\left(1786 \mathrm{~kg} \cdot \mathrm{ha}^{-1}\right)$. W okresie ostatnich 16 lat średnie plony nasion w Danii były zdecydowanie większe niż w innych czołowych (pod względem powierzchni upraw nasiennych) krajach - Szwecji, Niemczech i Polsce, odpowiednio o 79\%, 136\% i 156\% (rys. 5). Ta dysproporcja wskazuje, jak wiele działań należy podjąć w Polsce, mimo wzrostu wydajności plantacji nasiennych kostrzewy czerwonej w ostatnich latach, aby dorównać Danii pod względem plonu nasion odmian tego gatunku.

W reprodukcji odmian koniczyny łąkowej $\mathrm{w}$ analizowanym okresie najlepsze wyniki, co do plonowania plantacji nasiennych, odnotowano we Francji (rys. 5). Polska jako jeden z najważniejszych w Europie producentów nasion tego gatunku cechuje się mniejszym o 18\% plonowaniem 


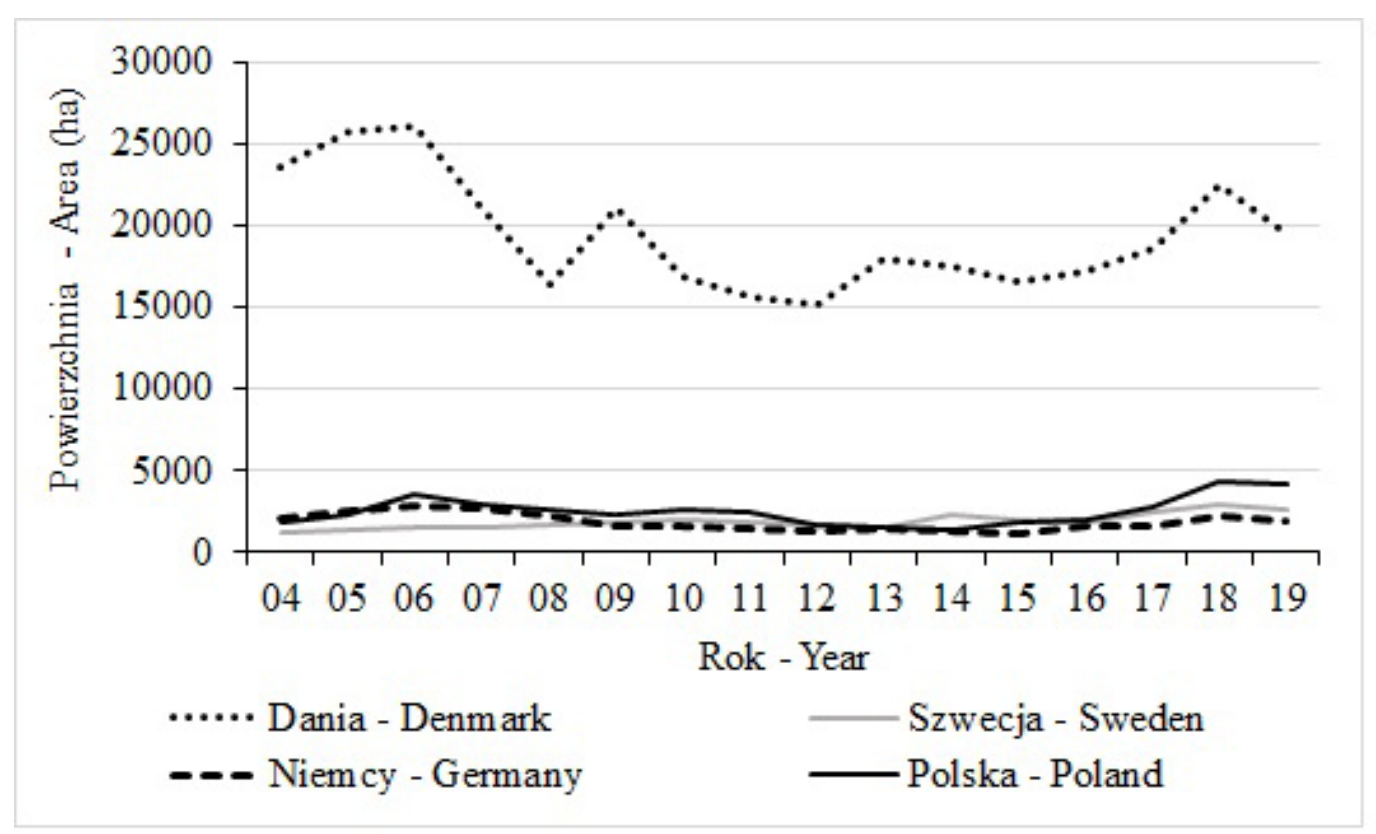

Rys. 3. Powierzchnia zakwalifikowanych upraw nasiennych kostrzewy czerwonej w wybranych krajach Europy w latach 2004-2019 (ha)

Fig. 3. Certified area of red fescue grown for seed in selected European countries in 2004-2019 (ha)

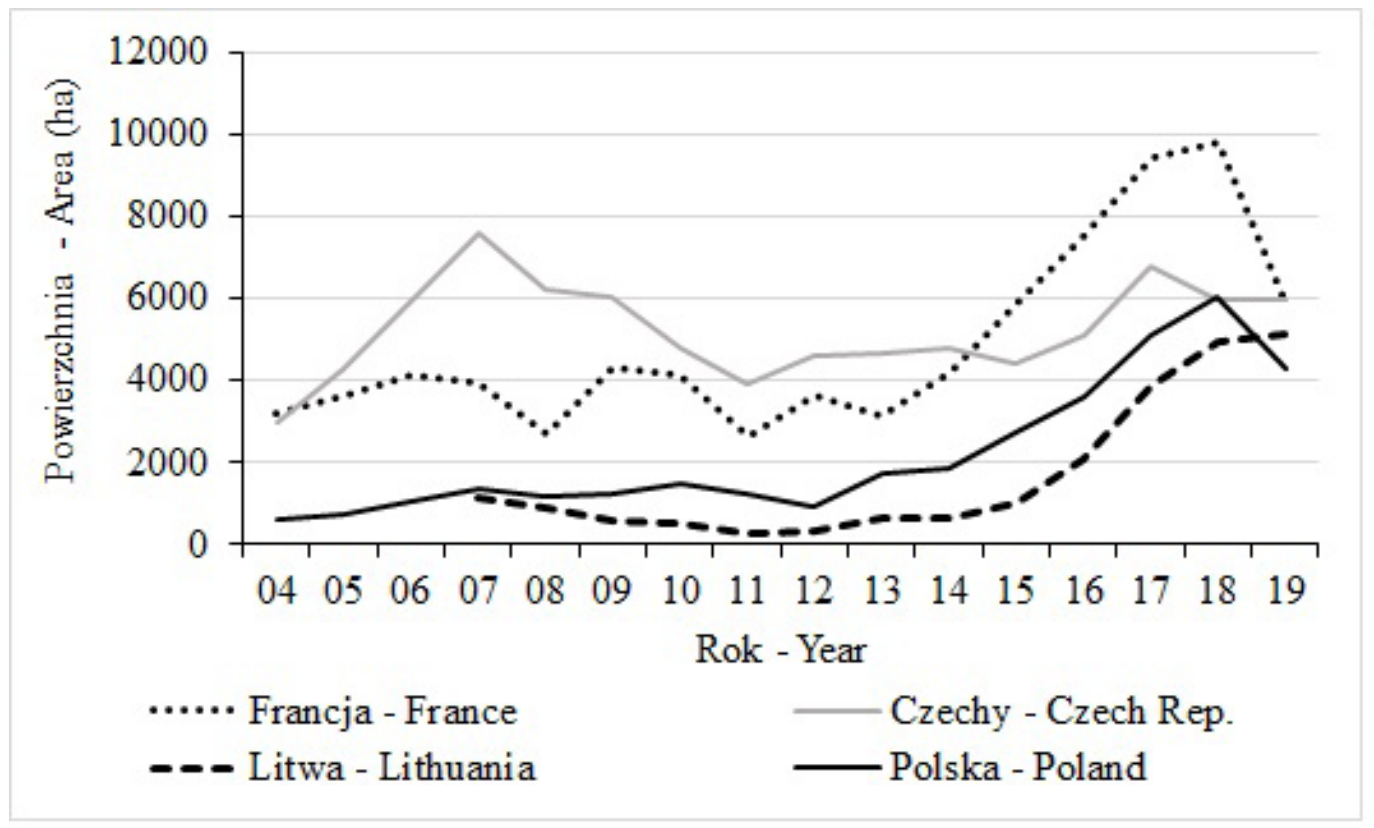

Rys. 4. Powierzchnia zakwalifikowanych upraw nasiennych koniczyny łąkowej w wybranych krajach Europy w latach 2004-2019 (ha)

Fig. 4. Certified area of red clover grown for seed in selected European countries in 2004-2019 (ha) 

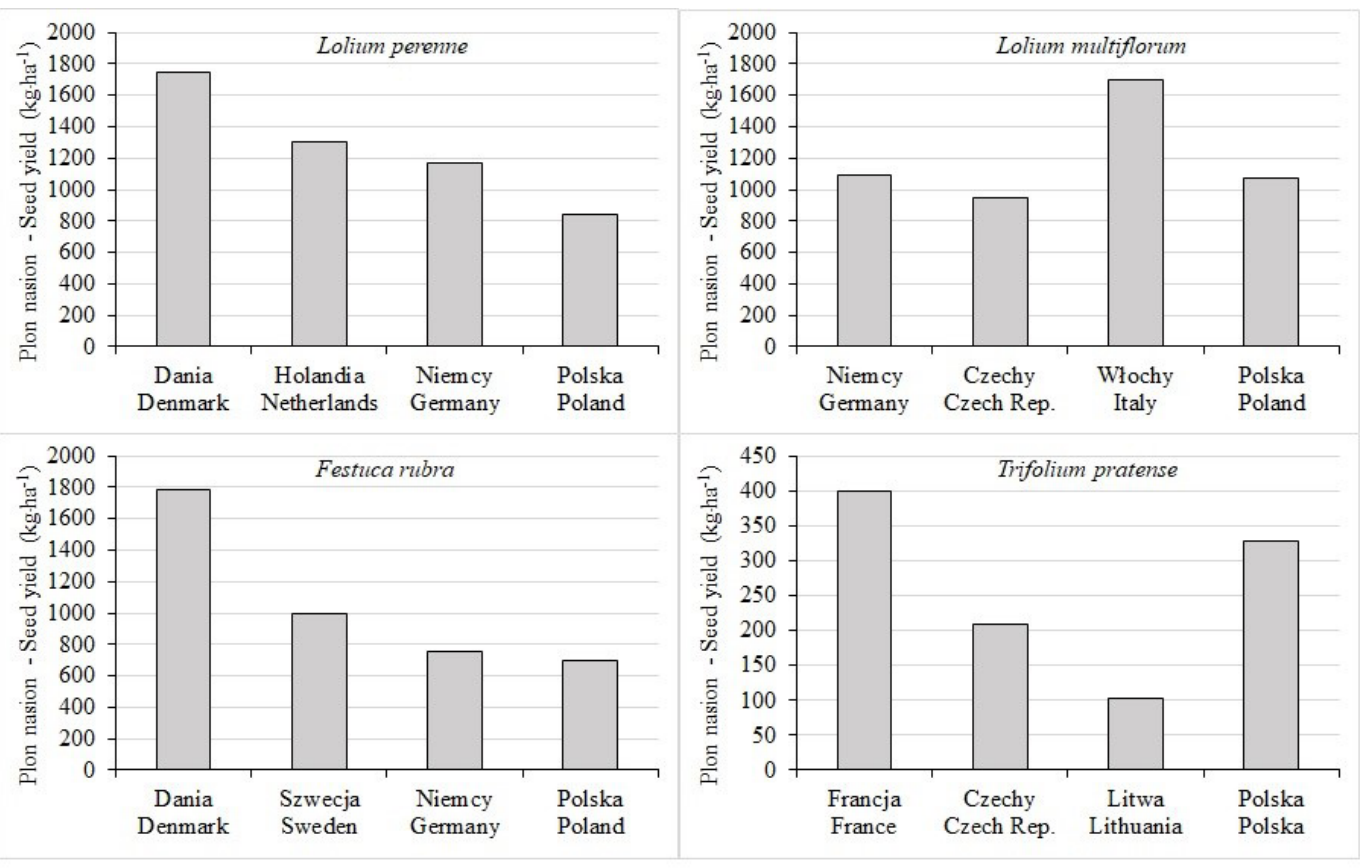

Rys. 5. Plon nasion wybranych gatunków traw i koniczyny ląkowej w wybranych krajach Europy w latach
\[ 2004-2019\left(\mathrm{~kg}^{-1}\right) \]

Fig. 5. Seed yield of selected grass species and red clover in selected European countries in 2004-2019 $\left(\mathbf{k g} \cdot \mathbf{h a}^{-1}\right)$

plantacji. Wykazywane przez ESCAA dane świadczą o małym plonie nasion $\mathrm{z}$ hektara uzyskiwanym przez Czechy i Litwę. Uzyskane wyniki budzą jednak wątpliwości, gdyż na tym tle trudna jest interpretacja dynamicznego w ostatnich latach rozwoju nasiennictwa koniczyny łąkowej w odniesieniu do areału plantacji nasiennych na Litwie przy ich plonowaniu na poziomie około $100 \mathrm{~kg} \cdot \mathrm{ha}^{-1}$.

Interesująca jest analiza powierzchni zakwalifikowanych plantacji traw i bobowatych drobnonasiennych w ostatnich czterech latach w Polsce na tle innych krajów, odgrywających wiodącą rolę na rynku nasiennym w Europie (tab. 1). Warto podkreślić, że w latach 2016-2019 areał upraw nasiennych traw zwiększał się z każdym rokiem we wszystkich krajach, poza Francją i Holandią w 2018 roku oraz Niemcami i Włochami w 2017 roku. W ocenianym okresie czteroletnim największy wzrost powierzchni zakwalifikowanych plantacji nasiennych stwierdzono w Danii i w Polsce, odpowiednio o $60 \%$ i $56 \%$, przy nieco mniejszym zwiększeniu we Francji, Czechach, Holandii i Niemczech, odpowiednio o $32 \%, 23 \%, 18 \%$ i $17 \%$ (tab. 2). $Z$ kolei wzrost areału upraw nasiennych traw w Szwecji był niewielki. Koniunktura na nasiona odmian pastewnych i gazonowych różnych gatunków traw uprawnych w ostatnich latach w Europie świadczy zarówno o zapotrzebowaniu materiału siewnego do zakładania i renowacji użytków zielonych do celów paszowych (Bailey i in., 2016; Huyghe i in., 2014), jak i o szerokim wykorzystywaniu nasion do celów nierolniczych, w tym sportowych, rekreacyjnych i urządzania terenów zieleni (Goliński, 2012).

W przypadku bobowatych kształtowanie się powierzchni w układzie rok do roku było zróżnicowane. Jednakże analiza okresu czteroletniego wskazuje na wyraźny wzrost areału upraw nasiennych tej grupy roślin w Polsce, Czechach i w Danii, odpowiednio o $27 \%$, 23\% i 14\%. W przypadku Szwecji wskaźnik ten nieznacznie zmniejszył się, a w Niemczech i Francji praktycznie nie zmienił się. Z kolei we Włoszech zwiększenie areału uprawy bobowatych drobnonasiennych w trzyletnim okresie 2016-2018 osiągnęło poziom 66,2\%. Wzrost całkowitej powierzchni plantacji nasiennych tej grupy roślin, zwłaszcza lucerny siewnej i różnych gatunków koniczyn należy łączyć z poszukiwaniem tanich źródeł białka w żywieniu przeżuwaczy i lepszym pod względem cech funkcjonalnych komponentów układaniem mieszanek nasiennych z trawami zarówno na przemienne, jak i na trwałe użytki zielone (Boller i in., 2010; Goliński i in., 2014; Wachendorf i Goliński, 2006).

W wyniku analizy danych stwierdzono, że polski rynek nasienny traw z upływem lat zajmuje coraz silniejszą pozycję w Europie. W ostatnich trzech latach udział Polski w ogólnej powierzchni 
Tabela 1

Table 1

Powierzchnia zakwalifikowanych upraw nasiennych traw i bobowatych drobnonasiennych w wybranych krajach Europy w latach 2016-2019 (ha)

Certified area of grasses and legumes grown for seed in selected European countries in 2016-2019 (ha)

\begin{tabular}{|c|c|c|c|c|c|c|c|c|}
\hline \multirow{2}{*}{$\begin{array}{c}\text { Kraj } \\
\text { Country }\end{array}$} & \multicolumn{4}{|c|}{ Trawy - Grasses } & \multicolumn{4}{|c|}{ Bobowate drobnonasienne - Legumes } \\
\hline & 2016 & 2017 & 2018 & 2019 & 2016 & 2017 & 2018 & 2019 \\
\hline $\begin{array}{l}\text { Polska } \\
\text { Poland }\end{array}$ & 16508 & 22138 & 24840 & 25690 & 3814 & 5606 & 5864 & 4856 \\
\hline $\begin{array}{c}\text { Czechy } \\
\text { Czech Rep. }\end{array}$ & 8370 & 9974 & 10040 & 10318 & 12175 & 16411 & 14547 & 15022 \\
\hline $\begin{array}{c}\text { Dania } \\
\text { Denmark }\end{array}$ & 57701 & 69146 & 84065 & 92036 & 3138 & 4081 & 4626 & 3587 \\
\hline $\begin{array}{l}\text { Francja } \\
\text { France }\end{array}$ & 10539 & 13106 & 13008 & 13940 & 28593 & 35236 & 38933 & 28619 \\
\hline $\begin{array}{c}\text { Holandia } \\
\text { Netherlands }\end{array}$ & 12992 & 13749 & 13426 & 15344 & - & - & - & - \\
\hline $\begin{array}{l}\text { Niemcy } \\
\text { Germany }\end{array}$ & 24752 & 23914 & 25635 & 28923 & 3007 & 3572 & 3394 & 2974 \\
\hline $\begin{array}{l}\text { Szwecja } \\
\text { Sweden }\end{array}$ & 11216 & 11234 & 11454 & 11614 & 4398,3 & 4643 & 4861 & 4148 \\
\hline $\begin{array}{l}\text { Włochy } \\
\text { Italy }\end{array}$ & 3728 & 3153 & 4532 & bd-nd & 42915 & 61703 & 71345 & bd-nd \\
\hline
\end{tabular}

Tabela 2

Table 2

Zmiany w powierzchni zakwalifikowanych upraw nasiennych traw i bobowatych drobnonasiennych w wybranych krajach Europy w latach 2016-2019 (\%)

Changes in certified area of grasses and legumes grown for seed in selected European countries in 2016-2019 (\%)

\begin{tabular}{|c|c|c|c|c|c|c|c|c|}
\hline \multirow{2}{*}{$\begin{array}{c}\text { Kraj } \\
\text { Country }\end{array}$} & \multicolumn{4}{|c|}{ Trawy - Grasses } & \multicolumn{4}{|c|}{ Bobowate drobnonasienne - Legumes } \\
\hline & $17 / 16$ & $18 / 17$ & $19 / 18$ & $19 / 16$ & $17 / 16$ & $18 / 17$ & $19 / 18$ & $19 / 16$ \\
\hline $\begin{array}{l}\text { Polska } \\
\text { Poland }\end{array}$ & $+34,1$ & $+12,2$ & $+3,4$ & $+55,6$ & $+47,0$ & $+4,6$ & $-17,2$ & $+27,3$ \\
\hline $\begin{array}{c}\text { Czechy } \\
\text { Czech Rep. }\end{array}$ & $+19,2$ & $+0,7$ & $+2,8$ & $+23,3$ & $+34,8$ & $-11,4$ & $+3,3$ & $+23,4$ \\
\hline $\begin{array}{c}\text { Dania } \\
\text { Denmark }\end{array}$ & $+19,8$ & $+21,6$ & $+9,5$ & $+59,5$ & $+30,0$ & $+13,4$ & $-22,5$ & $+14,3$ \\
\hline $\begin{array}{c}\text { Francja } \\
\text { France }\end{array}$ & $+24,4$ & $-0,7$ & $+7,2$ & $+32,3$ & $+23,2$ & $+10,5$ & $-26,5$ & $+0,1$ \\
\hline $\begin{array}{l}\text { Holandia } \\
\text { Netherlands }\end{array}$ & $+5,8$ & $-2,3$ & $+14,3$ & $+18,1$ & - & - & - & - \\
\hline $\begin{array}{l}\text { Niemcy } \\
\text { Germany }\end{array}$ & $-3,4$ & $+7,2$ & $+21,0$ & $+16,9$ & $+18,8$ & $-5,0$ & $-12,4$ & $-1,1$ \\
\hline $\begin{array}{l}\text { Szwecja } \\
\text { Sweden }\end{array}$ & $+0,2$ & $+2,0$ & $+1,4$ & $+3,5$ & $+5,6$ & $+4,7$ & $-14,7$ & $-5,7$ \\
\hline $\begin{array}{l}\text { Włochy } \\
\text { Italy }\end{array}$ & $-15,4$ & $+43,8$ & - & - & $+43,8$ & $+15,6$ & - & - \\
\hline
\end{tabular}


zakwalifikowanych plantacji nasiennych traw na rynku europejskim wynosił około 12,0\%. Niestety, w ujęciu wielkości produkcji kwalifikowanego materiału siewnego traw, udział naszego kraju w rynku jest mniejszy ze względu na mały plon nasion niektórych odmian hodowlanych. Analizując poszczególne gatunki traw wykazano, że w latach 2017-2019 w uprawie życicy wielokwiatowej i kostrzewy czerwonej Polska zajmowała drugie miejsce w Europie, a życicy trwałej - jako najważniejszej trawy na rynku nasiennym - drugie lub trzecie. W uprawie na nasiona wszystkich gatunków bobowatych drobnonasiennych nasz kraj w ostatnich trzech latach ma zaledwie około 3,5\% udziału w rynku europejskim. Przyczyną tego, jak już wspomniano, jest duże znaczenie w nasiennictwie jedynie koniczyny łąkowej.

W krajach zachodnioeuropejskich produkcja nasion większości gatunków traw jest większa od zapotrzebowania. Typowo proeksportowymi krajami w odniesieniu do materiału siewnego życic i kostrzew są Dania i Holandia. Podobny status w przypadku bobowatych drobnonasiennych mają Włochy i Francja. Pojawiają się jednak, nawet w krajach Europy Zachodniej, tak zwane nisze eksportowe, które stanowią dużą szansę dla polskich firm hodowlano-nasiennych i nasiennych. W przypadku traw wielkość eksportu nasion w ostatnich latach dochodzi do 4 tysięcy ton (dane PIN za rok 2016/2017). Polska posiada możliwości rozwijania nasiennictwa wielu gatunków traw i koniczyny łąkowej w najbliższych latach oraz zdobywania coraz lepszej pozycji na rynku europejskim. Należą do nich warunki siedliskowe, tradycje uprawy roślin łąkowych na nasiona, zaplecze techniczne i wiedza plantatorów, prężne i dobrze zorganizowane firmy nasienne (Podlaski, 2008; Majchrzycki i Pepliński, 2017) oraz niższe koszty jednostkowe produkcji nasion w porównaniu z krajami Europy Zachodniej.

\section{Wnioski}

1. Z upływem lat polski rynek nasienny traw zajmuje coraz silniejszą pozycję w Europie i wykazuje trend wzrostowy. Obecnie Polska zajmuje drugie miejsce w uprawie $L$. multiflorum i F. rubra, a w przypadku $L$. perenne jest jednym z trzech czołowych krajów rynku europejskiego.

2. W uprawie na nasiona roślin bobowatych drobnonasiennych Polska ma mniejsze znaczenie w Europie, jednak jest znaczącym producentem nasion $T$. pratense na rynku nasiennym z wyraźnym trendem wzrostu powierzchni plantacji tego gatunku w ostatnich latach.
3. Doskonalenie technologii upraw nasiennych traw i bobowatych drobnonasiennych w Polsce jest nadal aktualne, gdyż zbierane plony nasion są mniejsze $\mathrm{w}$ porównaniu do wiodących na rynku krajów europejskich. Zwiększenie wydajności plantacji nasiennych reprodukowanych odmian roślin łąkowych jest warunkiem wzrostu znaczenia naszego kraju w tej części rynku nasiennego w Europie.

\section{Literatura}

Bailey J., Brandsma J., Busqué J., Elsaesser M., Goliński P., Crespo D. G., Hopkins A., Hulin-Bertaud S., Krause A., Lind V., Mosquera-Losada M. R., Noorkõiv K., O’Donovan M., Peeters A., Pehrson I., Peratoner G., Porqueddu C., Raducescu L., Reheul D., van den Pol-van Dasselaar A., Osoro K., Iman B., Onega Q., Schreuder R. 2016. Profitability of permanent grassland. Final Report. EIP-AGRI Focus Group Permanent Grassland. European Commission: $1-44$.

Boelt B., Studer B. 2010. Breeding for grass seed yield. In: Boller B., Posselt U. K., Veronesi F. (eds.) Fodder Crops and Amenity Grasses. Handbook of Plant Breeding 5, Springer Science+Business Media, LLC: $161-174$.

Boller B., Schubiger F. X., Kölliker R., 2010. Red clover. In: Boller B., Posselt U. K., Veronesi F. (eds.) Fodder Crops and Amenity Grasses. Handbook of Plant Breeding 5, Springer Science+Business Media, LLC: $439-455$.

Chastain T.G., Young III W.C., Silberstein T.B., Garbacik C.J. 2014. Performance of trinexapac-ethyl on Lolium perenne seed crops in diverse lodging environments. Field Crops Research 157: 65 - 70.

Goliński P. 1996. Analiza kosztów i opłacalności produkcji nasion traw w wybranych gospodarstwach Wielkopolski. Biuletyn IHAR 199: $49-69$.

Goliński P. 2012. Hodowla traw i reprodukcja odmian. W: Kozłowski S. (red.) Trawy. Właściwości, występowanie i wykorzystanie. Powszechne Wydawnictwo Rolnicze i Leśne, Poznań: $71-81$.

Goliński P., Bailey J., Crespo D. G., van den Pol-van Dasselaar A., Lind V., Mosquera-Losada M. R., O’Donovan M., Peeters A., Porqueddu C., Reheul D. 2014. Sustainable grassland production by increased functional group diversification. EIP-AGRI Focus Group Permanent Grassland, European Commission: 1 - 7 .

Goliński P., Golińska B. 2015. Effect of application of preparations controlling the plant ripening process on seed shedding and yield of Lolium perenne. International Herbage Seed Group Newsletter 52: 18 - 20.

Goliński P., Golińska B. 2016. Status of seed production of grasses and legumes in Poland. International Herbage Seed Group Newsletter 55: 6 - 11 .

Goliński P., Jokś W., Golińska B., Puślednik M. 2008. Efektywność stosowania regulatorów wzrostu w uprawie 
nasiennej życicy trwałej. Progress in Plant Protection 48 (2): $586-589$.

Goliński P., Kozłowski S., Broda Z., Mikulski W. 2005. Prospects of grass utilisation in Poland and new approaches and goals in grass breeding. In: Zwierzykowski Z., Kosmala A. (eds.) Recent Advances in Genetics and Breeding of the Grasses., Institute of Plant Genetics PAS, Poznań, Poland: $147-162$.

Hart J.M., Anderson N.P., Chastain T.G., Flowers M.D., Ocamb C.M., Mellbye M.E., Young III W.C. 2013. Perennial ryegrass grown for seed (Western Oregon). Nutrient Management Guide, Oregon State University: 1 - 46.

Huyghe C., De Vliegher A., Goliński P. 2014. European grasslands overview: temperate region. Grassland Science in Europe 19: $29-40$.

Humphreys M., Feuerstein U., Vandewalle M., Baert J. 2010. Ryegrasses. In: Boller B., Posselt U. K., Veronesi F. (eds.) Fodder Crops and Amenity Grasses. Handbook of Plant Breeding 5, Springer Science+Business Media, LLC: $211-260$.

Kozłowski S., Goliński P. 2000. Trawy. W: Duczmal K., Tucholska H. (red.) Nasiennictwo. Tom 2. Państwowe Wydawnictwo Rolnicze i Leśne, Poznań: 125 - 173.

Majchrzycki D., Pepliński B. 2017. Analiza rynku kwalifikowanego materiału siewnego pszenicy ozimej. Roczniki Naukowe SERiA 19 (2): 158 - 164.

Martyniak J. 2009. Poziom krajowego nasiennictwa traw pastewnych a stan biologiczny użytków zielonych w Polsce. Woda-Środowisko-Obszary Wiejskie 9 (1): $21-38$.
Podlaski S. 2008. Model funkcjonowania firmy hodowlano -nasiennej w Polsce. Roczniki Nauk Rolniczych, Seria G 95 (1): $174-182$.

Qiu Y., Amirkhani M., Mayton H., Chen Z., Taylor A.G. 2020. Biostimulant seed coating treatments to improve cover crop germination and seedling growth. Agronomy 10, 154: doi:10.3390/agronomy10020154

Rognli O. A., Saha M. C., Bhamidimarri S., van der Heijden S. 2010. Fescues. In: Boller B., Posselt U. K., Veronesi F. (eds.) Fodder Crops and Amenity Grasses. Handbook of Plant Breeding 5, Springer Science+Business Media, LLC: $261-292$.

Rolston P., Trethewey J., McCloy B., Chynoweth R. 2007. Achieving forage ryegrass seed yield of $3000 \mathrm{~kg}$ $\mathrm{ha}^{-1}$ and limitations to higher yields. In: Aamlid T. S., Havstad L. T., Boelt B. (eds.) Seed production in the northern light. Proceedings of the sixth International Herbage Seed Conference, Bioforsk, Norway: $100-106$.

Van den Pol-van Dasselaar A., Goliński P., Hennessy D., Huyghe C., Parente G., Peyraud J.-L. 2014. Évaluation des fonctions des prairies par les acteurs européens. Fourrages 218: 141 - 146.

Wachendorf M., Goliński P. 2006. Towards sustainable intensive dairy farming in Europe. Grassland Science in Europe 11: $624-634$. 
